Jurnal Agroteknologi, Vol. 11 No. 2, Februari 2021: $45-52$

\title{
PENGARUH HERBISIDA METIL METSULFURON DAN KOMBINASINYA PADA PENGENDALIAN GULMA TANAMAN TEBU (Saccharum officinarum L.)
}

\author{
(The Effect of Methyl Methulfuron Herbicide and Combination on Controlling Sugarcane Weed \\ (Saccharum officinarum L.))
}

\author{
M. AZIZ SETIAWAN ${ }^{1 *}$, SISMITA SARI $^{1}$, MIRODI SYOFIAN $^{1}$ \\ ${ }^{1}$ Program Studi Produksi dan Manajemen Industri Perkebunan, \\ Jurusan Budidaya Tanaman Perkebunan, Politeknik Negeri Lampung \\ Jl. Soekarno Hataa No. 10, Rajabasa Bandar Lampung \\ *E-mail: Mazizstt@gmail.com
}

\begin{abstract}
Weed control should use appropriate herbicide doses so as not to leave residual effects on cultivated crops and soil. This study aims to obtain the most appropriate herbicide dose. The herbicide used in this research is a combination of methyl methulfurone and acetic acid. This study used a randomized block design (RAK) witch 2 factors, factor $A$ was acetic acid and factor $B$ was methyl methulfurone and there were 12 treatment combinations with 3 replications. This research was conducted in the practice area of the Department of Plantation Crops at Lampung State Polytechnic. The total research plot was 36 experimental units. The dosage levels of methyl methulfurone tested in this study were: $0 \%, 55 \%, 75 \%$, and $105 \%$. While the doses of acetic acid are: $0 \%, 50 \%$, and $70 \%$. The observations made in this study were the analysis of weed vegetation, percent weed cover, weed dry weight, Summed Dominance Ratio (SDR), and Community Coefficient Value (C). The SDR value indicated that Panicum dicotomyflorum, Ricardia brasiliensis, Euphorbia heterophyla, and Cyperus rotundus were the dominant weeds. The results of this study indicated that there was no effect of the herbicide dose of methyl methulfurone, acetic acid, and the interaction of the herbicide methyl methulfuron and acetic acid on weed control in sugarcane fields (Saccharum officinarum L.).
\end{abstract}

Keyword: acetic acid, methyl methulfuron herbicide, sugarcane weed

\section{PENDAHULUAN}

Tanaman tebu (Saccharum officinarum L.) merupakan salah satu komoditi penting dalam bidang pertanian yang menghasilkan produk gula. Loganadhan et al. (2012) menyatakan bahwa tebu dapat menjadi salah satu tanaman yang dapat menyumbang perekonomian nasional dan sumber mata pencaharian bagi jutaan petani. Sebagai produk olahan tebu, gula merupakan komoditas penting bagi masyarakat dan perekonomian Indonesia baik sebagai kebutuhan pokok maupun sebagai bahan baku industri makanan atau minuman.

Pertumbuhan gulma (weed) dapat mengganggu tanaman budidaya akibat beberapa hal diantara lain: persaingan untuk untuk mengambil air, nutrisi, sinar matahari, dan persaingan habitat. Tidak ada keharusan untuk membunuh seluruh gulma pada pengendaliannya, melainkan cukup menekan pertumbuhan gulma dan mengurangi jumlah populasi gulma (Pramuhadi, 2012).

Gulma yang dibiarkan tumbuh pada lahan tanaman tebu yang berumur hingga 11 bulan akan menurunkan jumlah batang pada umur 3 dan 6 bulan masing-masing sebesar $26,94 \%$ dan $19,62 \%$. Selain menurunkan jumlah batang, gulma dapat menurunkan produksi tebu dan hasil gula sebesar $15,81 \%$ dan 21,80\% (Puspitasari, Sebayang, \& Guritno, 2013).

Pengendalian gulma dapat dikendalikan dengan beberapa metode yaitu: pengendalian mekanis, kultur teknis, dan kimia. Penelitian ini menggunakan metode pengendalian gulma dengan cara kimia (herbisida). Penggunaan herbisida harus tepat sasaran karena mengandung bahan kimia yang dapat mengganggu tanaman pokok (Sukman \& Yakub, 2002).

Metil metsulfuron adalah herbisida sistemik yang dapat digunakan sebagai herbisida sebelum tanam dan sesudah tanam. Metil metsulfuron bekerja dengan cara memberhentikan pembelahan sel dan 
pertumbuhan gulma dengan cepat yang mengandung bahan aktif rendah hanya $20 \%$ dibanding herbisida lain yang bahan aktifnya sekitaf $80 \%$ (Wijaya \& Nursyirwan, 2007).

Penelitian ini menggunakan kombinasi asam asetat sebagai paraquat. Asam asetat merupakan herbisida kontak yang dapat merusak membran sel dengan cepat sehingga menyebabkan daun mengering (Pujisiswanto et al., 2014). Sifat kimia pada herbisida dapat menentukan daya kerja pada gulma, tingkat keracunan (toksitas) pada makhluk hidup yang bukan sasaran, dan lingkungan (Sembodo, 2010).

Tujuan penelitian ini adalah untuk mendapatkan dosis herbisida metil metsulfurpon dan asam asetat yang paling tepat untuk mengendalikan gulma di lahan tebu dan mendapatkan interaksi antara metil metsulfuron dan asam asetat terhadap mortalitas gulma.

\section{BAHAN DAN METODE}

Penelitian dilaksanakan pada bulan September hingga November 2018 di lahan tebu Jurusan Budidaya Tanaman Perkebunan, Politeknik Negeri Lampung. Alat yang digunakan dalam penelitian ini adalah ember, gunting, penggaris, timbangan analitik, gelas ukur, dan sprayer. Bahan-bahan yang digunakan adalah herbisida metil metsulfuron, asam asetat, bambu patok, tali rafia, dan air. Pengambilan sampel gulma dilakukan dengan cara kuadran yang berukuran $50 \mathrm{~cm}$ $x 33,3 \mathrm{~cm}$. Sampel gulma diambil dengan cara memotong gulma menggunakan sabit 1 - $3 \mathrm{~cm}$ diatas permukaan tanah. Volume semprot yang digunakan pada penelitian ini adalah $45 \mathrm{ml} \cdot \mathrm{m}^{-2}$. Aplikasi herbisida dilakukan pada pukup 08.00 - 10.00 WIB dengan cuaca yang cerah dengan cara menyemprotkan larutan herbisida dengan menggunakan alat berupa tangki semprot

Penelitian ini menggunakan Rancangan Acak Kelompok (RAK) dengan 2 faktor yaitu asam asetat (dosis $0 \%, 50 \%$, dan $70 \%$ ) dan herbisida metil metsulfuron (dosis $0 \%, 55 \%$, $75 \%$, dan $105 \%$ ). Terdiri dari 12 perlakuan dengan 3 ulangan, sehingga terdapat 36 satuan percobaan.

Pengamatan dilakukan pada 0 MSA, 1 MSA, 2 MSA, 3 MSA, 4 MSA, dan 5 MSA. Variabel yang diamati adalah analisis vegetasi gulma, persen penutupan gulma, bobot kering gulma, Summed Dominance Ratio SDR, dan nilai koefisien komunitas (C).

Analisis data yang digunakan adalah analisis ragam apabila berbeda nyata dilanjutkan dengan uji Berbeda Nyata Terkecil (BNT) pada taraf 5\%.

\section{HASIL DAN PEMBAHASAN}

\section{Analisis Vegetasi Gulma}

Hasil identifikasi vegetasi gulma di lahan praktikum tanaman tebu Jurusan Budidaya Tanaman Perkebunan, Politeknik Negeri Lampung terdapat 28 spesies gulma yang terbagi mejadi 3 jenis gulma. Spesies gulma yang tumbuh di lahan percobaan dapat dilihat pada Tabel 1.

Tabel 1. Spesies gulma pada lahan percobaan

\begin{tabular}{|c|c|c|c|}
\hline \multirow[b]{2}{*}{ No } & \multicolumn{3}{|c|}{ Jenis Gulma } \\
\hline & Daun Lebar & Daun Sempit & $\begin{array}{l}\text { Teki- } \\
\text { tekian }\end{array}$ \\
\hline 1 & $\begin{array}{l}\text { Asystasia } \\
\text { gangentica }\end{array}$ & $\begin{array}{l}\text { Digitaria } \\
\text { ciliaris }\end{array}$ & $\begin{array}{l}\text { Cyperus } \\
\text { rotundus }\end{array}$ \\
\hline 2 & $\begin{array}{l}\text { Axonopus } \\
\text { compresus }\end{array}$ & $\begin{array}{l}\text { Eciniclhoa } \\
\text { colonum }\end{array}$ & \\
\hline 3 & $\begin{array}{l}\text { Borreria } \\
\text { alata }\end{array}$ & Eleusine indica & \\
\hline 4 & $\begin{array}{l}\text { Borreria } \\
\text { leavis }\end{array}$ & $\begin{array}{l}\text { Panicum } \\
\text { dicotomyflorum }\end{array}$ & \\
\hline 5 & $\begin{array}{l}\text { Cleome } \\
\text { ruditospermae }\end{array}$ & $\begin{array}{l}\text { Pannisetum } \\
\text { purpureum }\end{array}$ & \\
\hline 6 & $\begin{array}{l}\text { Crassocephalum } \\
\text { crepidiodes }\end{array}$ & & \\
\hline 7 & Crotoh hirtus & & \\
\hline 8 & Croton sp & & \\
\hline 9 & $\begin{array}{l}\text { Euphorbia } \\
\text { heteropila }\end{array}$ & & \\
\hline 10 & $\begin{array}{l}\text { Euphorbia } \\
\text { Hirta }\end{array}$ & & \\
\hline 11 & $\begin{array}{l}\text { Ipomoea } \\
\text { Triloba }\end{array}$ & & \\
\hline 12 & $\begin{array}{l}\text { Mimos } \\
\text { Invisa }\end{array}$ & & \\
\hline 13 & $\begin{array}{l}\text { Mimosa } \\
\text { Pudica }\end{array}$ & & \\
\hline 14 & Oxalis sp & & \\
\hline 15 & $\begin{array}{l}\text { Porofilum } \\
\text { rudelae }\end{array}$ & & \\
\hline 16 & Pylantus niruri & & \\
\hline 17 & $\begin{array}{l}\text { Ricardia } \\
\text { brasiliensis }\end{array}$ & & \\
\hline 18 & $\begin{array}{l}\text { Setaria } \\
\text { Pelicata }\end{array}$ & & \\
\hline 19 & $\begin{array}{l}\text { Sida } \\
\text { Rombifilia }\end{array}$ & & \\
\hline 20 & $\begin{array}{l}\text { Sinedrella } \\
\text { Nudiflora }\end{array}$ & & \\
\hline 21 & $\begin{array}{l}\text { Spegelia } \\
\text { anthelmia }\end{array}$ & & \\
\hline 22 & $\begin{array}{l}\text { Stacitaperta } \\
\text { indica }\end{array}$ & & \\
\hline
\end{tabular}




\section{Persen Penutupan Gulma}

Hasil dari analisis sidik ragam persen penutupan gulma menunjukkan tidak berbeda nyata yang dapat dilihat pada Tabel 2. Hal ini dikarenakan herbisida metil metsulfuron dan asam asetat yang diberikan belum mampu mengendalikan gulma di lahan tanaman tebu (Saccharum officinarum L.). Gulma berdaun lebar sulit dikendalikan dikarenakan perkembangbiakannya melalui biji (Sastroutomo, 1990).

\section{Bobot Kering Gulma}

Cahaya, suhu, curah hujan, kandungan bahan organik, kelembaban, dan $\mathrm{pH}$ adalah faktor lingkungan yang memengaruhi efektifitas herbisida yang diaplikasikan (Barus, 2003). Hasil dari analisis sidik ragam bobot kering gulma dapat dilihat pada Tabel 3 yang menunjukkan hasil tidak berbeda nyata.

Tabel 2. Hasil analisis sidik ragam persen penutupan gulma

\begin{tabular}{|c|c|c|c|c|c|c|}
\hline \multirow{2}{*}{ Perlakuan } & \multicolumn{6}{|c|}{ Persen Penutupan Gulma } \\
\hline & $0 \mathrm{MSA}$ & $1 \mathrm{MSA}$ & $2 \mathrm{MSA}$ & $3 \mathrm{MSA}$ & $4 \mathrm{MSA}$ & $5 \mathrm{MSA}$ \\
\hline \multicolumn{7}{|l|}{ Metil metsulfuron } \\
\hline $0 \%$ & $25,56^{a}$ & $24,00^{a}$ & $10,67^{a}$ & $12,22^{a}$ & $32,89^{a}$ & $23,89^{a}$ \\
\hline $55 \%$ & $19,22^{a}$ & $21,67^{\mathrm{a}}$ & $6,89^{a}$ & $3,67^{a}$ & $27,78^{a}$ & $17,33^{a}$ \\
\hline $75 \%$ & $25,11^{a}$ & $16,89^{a}$ & $7,22^{a}$ & $3,44^{a}$ & $25,33^{a}$ & $12,00^{a}$ \\
\hline $105 \%$ & $22,56^{a}$ & $12,22^{a}$ & $5,89^{a}$ & $4,22^{a}$ & $24,33^{a}$ & $19,56^{a}$ \\
\hline BNT 0.05 & $5,50^{\mathrm{ns}}$ & $12,07^{\mathrm{ns}}$ & $1,71^{\mathrm{ns}}$ & $4,39^{\mathrm{ns}}$ & $8,11^{\mathrm{ns}}$ & $10,62^{\mathrm{ns}}$ \\
\hline \multicolumn{7}{|l|}{ Asam asetat } \\
\hline $0 \%$ & $19,83^{a}$ & $25,75^{a}$ & $10,50^{\mathrm{a}}$ & $3,58^{a}$ & $30,42^{a}$ & $22,33^{a}$ \\
\hline $50 \%$ & $20,83^{a}$ & $20,42^{a}$ & $9,58^{a}$ & $4,67^{a}$ & $32,42^{a}$ & $18,92^{a}$ \\
\hline $70 \%$ & $28,67^{\mathrm{a}}$ & $17,67^{\mathrm{a}}$ & $2,92^{\mathrm{a}}$ & $9,42^{a}$ & $19,92^{a}$ & $13,33^{a}$ \\
\hline BNT 0.05 & $6,35^{\mathrm{ns}}$ & $13,94^{\mathrm{ns}}$ & $1,97^{\text {ns }}$ & $5,06^{\mathrm{ns}}$ & $9,36^{\text {ns }}$ & $11,57^{\mathrm{ns}}$ \\
\hline
\end{tabular}

Keterangan: angka-angka pada kolom yang diikuti huruf yang sama menunjukkan antar perlakuan tidak berbeda nyata pada uji BNT taraf kepercayaan $5 \%$

Tabel 3. Analisis sidik ragam bobot kering gulma

\begin{tabular}{|c|c|c|c|c|c|c|}
\hline \multirow{2}{*}{ Perlakuan } & \multicolumn{6}{|c|}{ Bobot Kering Gulma (gram) } \\
\hline & $0 \mathrm{MSA}$ & $1 \mathrm{MSA}$ & $2 \mathrm{MSA}$ & $3 \mathrm{MSA}$ & $4 \mathrm{MSA}$ & $5 \mathrm{MSA}$ \\
\hline \multicolumn{7}{|l|}{ Metil metsulfuron } \\
\hline $0 \%$ & $7,13^{a}$ & $7,15^{a}$ & $1,19^{a}$ & $3,89^{a}$ & $3,86^{a}$ & $9,88^{a}$ \\
\hline $55 \%$ & $4,51^{\mathrm{a}}$ & $4,74^{\mathrm{a}}$ & $1,50^{\mathrm{a}}$ & $0,52^{a}$ & $7,28^{a}$ & $7,40^{a}$ \\
\hline $75 \%$ & $8,20^{a}$ & $3,55^{a}$ & $0,58^{a}$ & $0,69^{a}$ & $2,30^{a}$ & $1,84^{\mathrm{a}}$ \\
\hline $105 \%$ & $6,94^{a}$ & $2,40^{a}$ & $1,08^{a}$ & $0,27^{\mathrm{a}}$ & $10,63^{a}$ & $6,87^{\mathrm{a}}$ \\
\hline BNT 0.05 & $5,50^{\mathrm{ns}}$ & $4,69^{\mathrm{ns}}$ & $1,71^{\mathrm{ns}}$ & $4,39^{\text {ns }}$ & $8,11^{\text {ns }}$ & $6,33^{\mathrm{ns}}$ \\
\hline \multicolumn{7}{|l|}{ Asam asetat } \\
\hline $0 \%$ & $5,26^{a}$ & $8,23^{a}$ & $1,85^{a}$ & $0,25^{a}$ & $5,72^{a}$ & $9,14^{\mathrm{a}}$ \\
\hline $50 \%$ & $5,61^{a}$ & $5,49^{a}$ & $1,33^{a}$ & $0,87^{a}$ & $6,95^{\mathrm{a}}$ & $6,56^{a}$ \\
\hline $70 \%$ & $9,22^{a}$ & $4,12^{a}$ & $0,09^{a}$ & $2,91^{a}$ & $5,38^{a}$ & $3,80^{a}$ \\
\hline BNT 0.05 & $6,35^{\mathrm{ns}}$ & $5,42^{\text {ns }}$ & $1,98^{\text {ns }}$ & $5,07^{\mathrm{ns}}$ & $9,36^{\text {ns }}$ & $7,31^{\mathrm{ns}}$ \\
\hline
\end{tabular}


Pengaruh Herbisida Metil Metsulfuron Terhadap Gulma Tanaman Tebu (Setiawan, et al.)

\section{Summed Dominance Ratio (SDR)}

Nilai SDR digunakan untuk mengetahui dominasi spesies gulma. Dominasi suatu gulma setelah dikendalikan dengan herbisida akan erat hubungannya dengan pengendalian secara kimia pada musim berikutnya, karena gulma yang dominan akan disesuaikan dengan jenis herbisida (Prasetyo, 2016). Gulma yang dominan dapat dilihat pada Gambar 1 sampai Gambar 12.

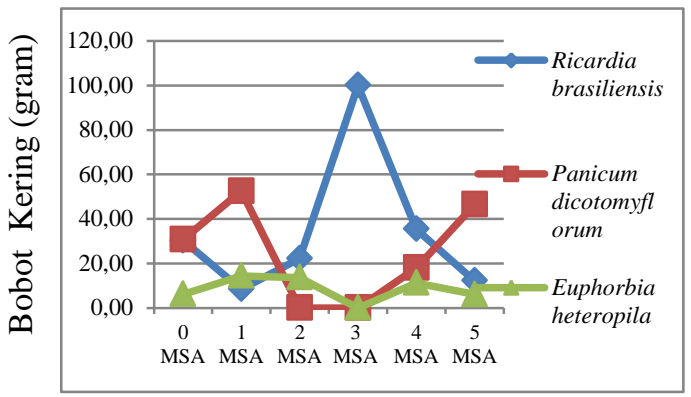

Gambar 1. Perbandingan bobot kering tanpa perlakuan

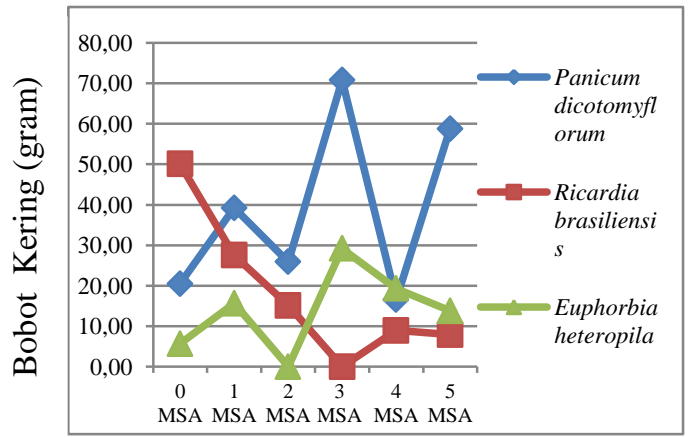

Gambar 2. Perbandingan bobot kering gulma pada perlakuan $\mathrm{A}_{0} \mathrm{M}_{1}$

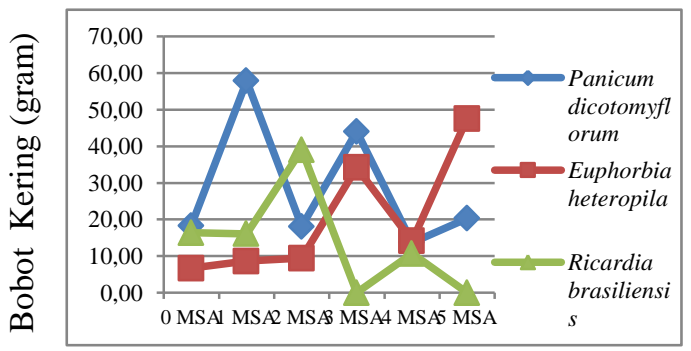

Jambar 3.Perbandingan bobot kering gulma pada perlakuan $\mathrm{A}_{0} \mathrm{M}_{2}$

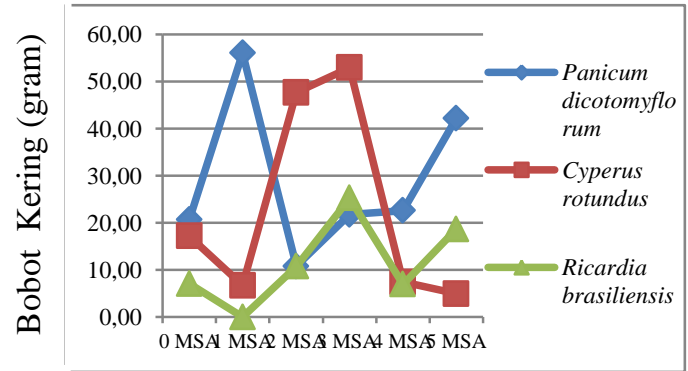

Gambar 4. Perbandingan bobot kering gulma pada perlakuan $\mathrm{A}_{0} \mathrm{M}_{3}$

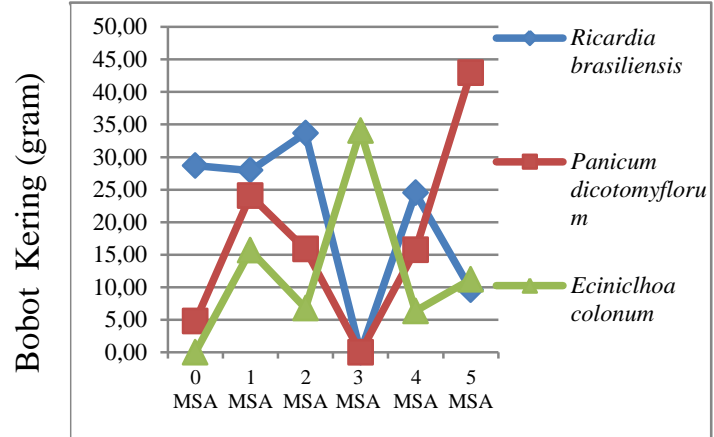

Gambar 5. Perbandingan bobot kering $A_{1} M_{0}$

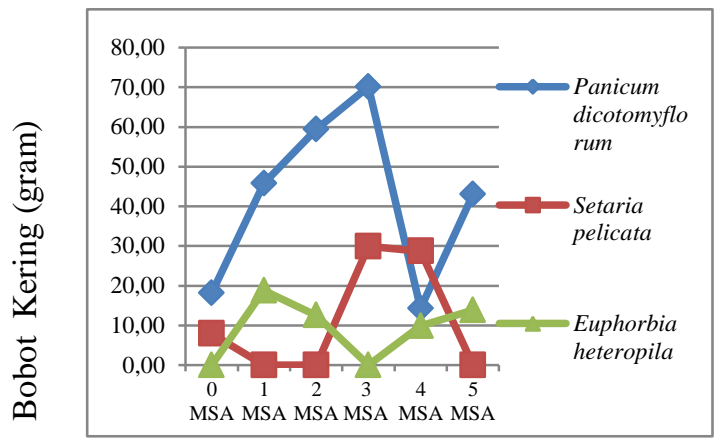

Gambar 6. Perbandingan bobot kering $A_{1} M_{1}$

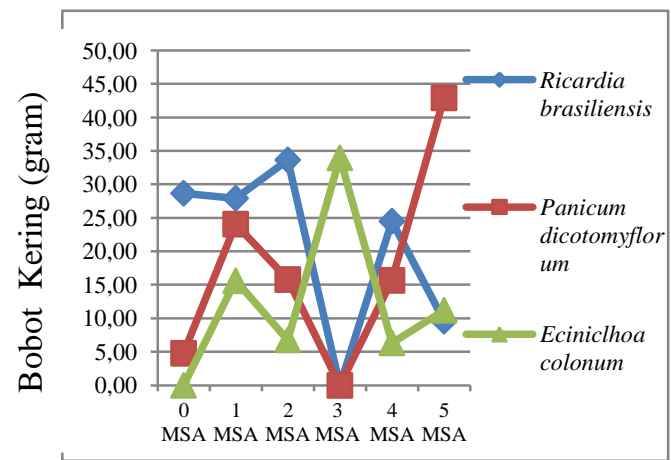

Gambar 7. Perbandingan bobot kering $A_{1} M_{2}$

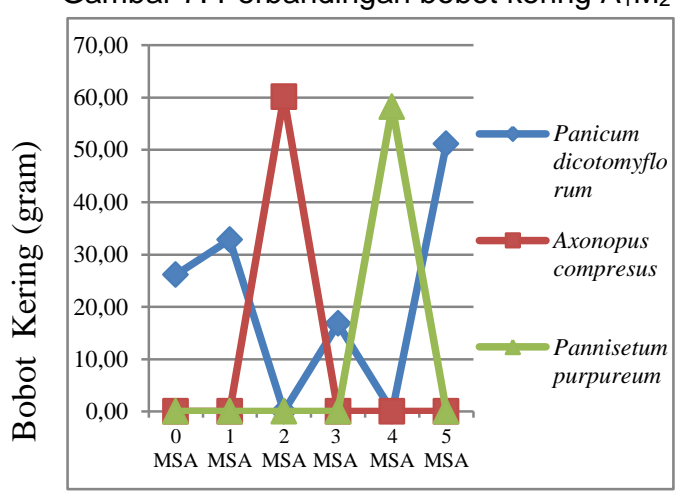

Gambar 8. Perbandingan bobot kering $A_{1} M_{3}$

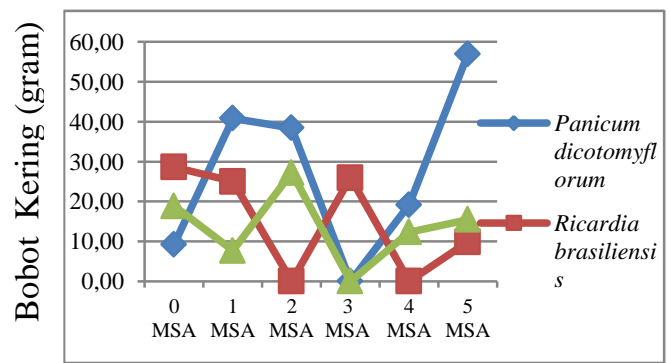

Gambar 9. Perbandingan bobot kering $\mathrm{A}_{2} \mathrm{M}_{0}$ 


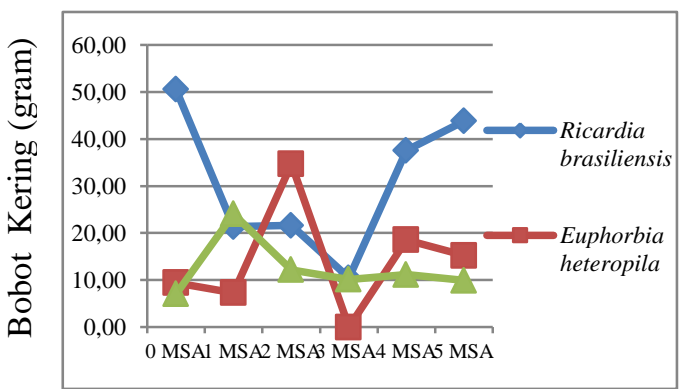

Gambar 10. Perbandingan bobot kering $\mathrm{A}_{2} \mathrm{M}_{1}$

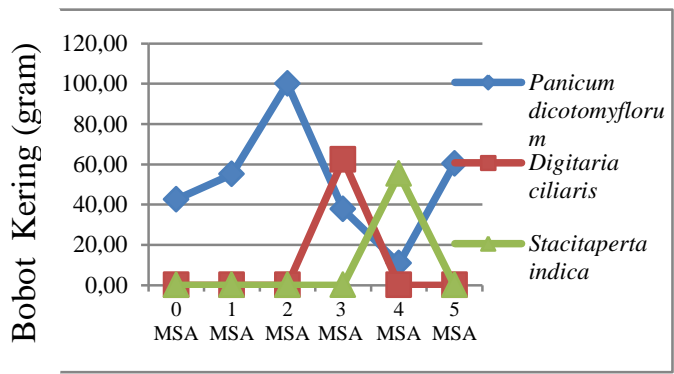

Gambar 12. Perbandingan bobot kering $\mathrm{A}_{2} \mathrm{M}_{3}$

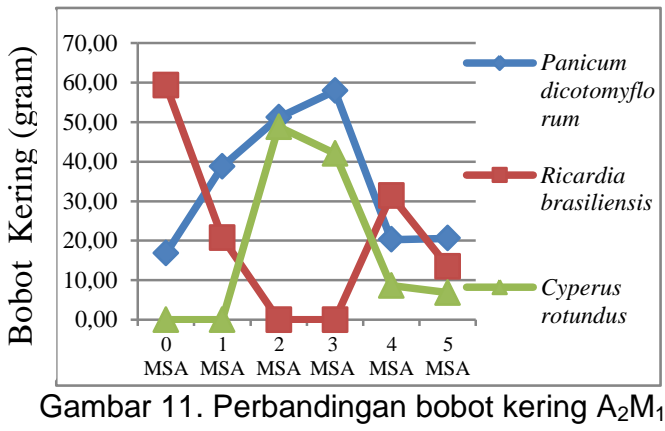

Gulma Panicum dicotomyflorum, Ricardia brasiliensis, Euphorbia heterophila, Ecinoclhoa colonum adalah gulma yang dominan yang terdapat pada lahan percobaan penelitian. Tumbuhan yang tajuknya lebih rimbun dan tanaman yang tinggi (tumbuh lebih cepat) akan memperoleh cahaya lebih banyak, sedangkan tumbuhan yang pendek akan mendapatkan cahaya sedikit dikarenakan ternaungi oleh tumbungan yang lebih tinggi (Sukman \& Yakub, 2002).

Tabel 4. Nilai koefisien komunitas masing-masing perlakuan

\begin{tabular}{|c|c|c|c|c|c|c|}
\hline \multirow{2}{*}{ Perbandingan Perlakuan } & \multicolumn{6}{|c|}{ Koefisien Komunitas (\%) } \\
\hline & $0 \mathrm{MSA}$ & $1 \mathrm{MSA}$ & $2 \mathrm{MSA}$ & $3 \mathrm{MSA}$ & $4 \mathrm{MSA}$ & $5 \mathrm{MSA}$ \\
\hline$(0)$ & (1) & (2) & (3) & (4) & (5) & (6) \\
\hline$A_{0} M_{0}: A_{0} M_{1}$ & 68,73 & 66,40 & 15,16 & 0,00 & 36,75 & 66,02 \\
\hline$A_{0} M_{0}: A_{0} M_{2}$ & 49,75 & 69,57 & 31,64 & 0,00 & 40,56 & 32,63 \\
\hline$A_{0} M_{0}: A_{0} M_{3}$ & 51,45 & 77,80 & 21,57 & 25,26 & 42,40 & 75,72 \\
\hline$A_{0} M_{0}: A_{1} M_{0}$ & 61,23 & 41,94 & 28,70 & 0,00 & 56,36 & 76,99 \\
\hline$A_{0} M_{0}: A_{1} M_{1}$ & 44,77 & 69,68 & 12,57 & 0,00 & 29,87 & 67,28 \\
\hline$A_{0} M_{0}: A_{1} M_{2}$ & 63,40 & 44,13 & 10,54 & 0,00 & 23,31 & 64,47 \\
\hline$A_{0} M_{0}: A_{1} M_{3}$ & 55,34 & 67,46 & 6,52 & 0,00 & 15,04 & 59,10 \\
\hline$A_{0} M_{0}: A_{2} M_{0}$ & 63,08 & 53,54 & 35,24 & 10,44 & 68,52 & 34,17 \\
\hline$A_{0} M_{0}: A_{2} M_{1}$ & 62,32 & 68,18 & 13,64 & 25,95 & 29,10 & 62,35 \\
\hline$A_{0} M_{0}: A_{2} M_{2}$ & 62,39 & 74,69 & 0,00 & 0,00 & 64,16 & 45,01 \\
\hline$A_{0} M_{0}: A_{2} M_{3}$ & 48,11 & 78,63 & 0,00 & 0,00 & 16,19 & 66,00 \\
\hline$A_{0} M_{1}: A_{0} M_{2}$ & 46,95 & 68,14 & 50,02 & 73,23 & 56,71 & 40,55 \\
\hline$A_{0} M_{1}: A_{0} M_{3}$ & 33,08 & 55,05 & 21,52 & 21,78 & 40,17 & 68,66 \\
\hline$A_{0} M_{1}: A_{1} M_{0}$ & 47,15 & 70,05 & 37,76 & 0,00 & 36,94 & 62,84 \\
\hline$A_{0} M_{1}: A_{1} M_{1}$ & 33,78 & 63,44 & 25,90 & 70,09 & 29,87 & 56,85 \\
\hline$A_{0} M_{1}: A_{1} M_{2}$ & 48,69 & 43,53 & 25,90 & 20,46 & 24,03 & 76,14 \\
\hline$A_{0} M_{1}: A_{1} M_{3}$ & 38,99 & 59,37 & 44,43 & 35,46 & 10,03 & 70,21 \\
\hline $\mathrm{A}_{0} \mathrm{M}_{1}: \mathrm{A}_{2} \mathrm{M}_{0}$ & 70,68 & 57,02 & 27,34 & 10,14 & 38,73 & 31,68 \\
\hline $\mathrm{A}_{0} \mathrm{M}_{1}: \mathrm{A}_{2} \mathrm{M}_{1}$ & 5,68 & 79,88 & 0,00 & 0,00 & 28,94 & 85,17 \\
\hline$A_{0} M_{1}: A_{2} M_{2}$ & 75,63 & 71,37 & 25,90 & 57,94 & 34,19 & 55,41 \\
\hline$A_{0} M_{1}: A_{2} M_{3}$ & 41,04 & 72,67 & 25,90 & 37,65 & 65,84 & 78,93 \\
\hline$A_{0} M_{2}: A_{0} M_{3}$ & 48,57 & 64,68 & 42,07 & 21,78 & 46,95 & 45,44 \\
\hline$A_{0} M_{2}: A_{1} M_{0}$ & 61,70 & 48,74 & 72,88 & 21,75 & 60,86 & 43,48 \\
\hline$A_{0} M_{2}: A_{1} M_{1}$ & 37,27 & 61,46 & 38,63 & 65,80 & 39,86 & 52,51 \\
\hline$(0)$ & (1) & (2) & (3) & (4) & (5) & (6) \\
\hline
\end{tabular}




\begin{tabular}{|c|c|c|c|c|c|c|}
\hline$A_{0} M_{2}: A_{1} M_{2}$ & 56,30 & 37,98 & 33,08 & 42,21 & 28,16 & 41,07 \\
\hline$A_{0} M_{2}: A_{1} M_{3}$ & 42,55 & 50,82 & 18,97 & 35,46 & 26,00 & 29,29 \\
\hline $\mathrm{A}_{0} \mathrm{M}_{2}: \mathrm{A}_{2} \mathrm{M}_{0}$ & 43,07 & 47,41 & 48,78 & 10,14 & 40,89 & 25,15 \\
\hline $\mathrm{A}_{0} \mathrm{M}_{2}: \mathrm{A}_{2} \mathrm{M}_{1}$ & 43,71 & 72,05 & 38,63 & 21,75 & 53,08 & 44,74 \\
\hline $\mathrm{A}_{0} \mathrm{M}_{2}: \mathrm{A}_{2} \mathrm{M}_{2}$ & 36,37 & 62,33 & 29,17 & 44,05 & 51,23 & 72,49 \\
\hline$A_{0} M_{2}: A_{2} M_{3}$ & 35,72 & 79,57 & 18,08 & 37,65 & 39,17 & 41,76 \\
\hline$A_{0} M_{3}: A_{1} M_{0}$ & 34,00 & 40,21 & 35,71 & 14,99 & 57,21 & 76,86 \\
\hline$A_{0} M_{3}: A_{1} M_{1}$ & 47,80 & 67,55 & 36,60 & 21,78 & 48,39 & 71,77 \\
\hline$A_{0} M_{3}: A_{1} M_{2}$ & 49,53 & 47,58 & 21,30 & 20,46 & 57,99 & 68,13 \\
\hline$A_{0} M_{3}: A_{1} M_{3}$ & 41,28 & 61,44 & 14,19 & 30,32 & 25,20 & 63,88 \\
\hline$A_{0} M_{3}: A_{2} M_{0}$ & 46,44 & 42,76 & 32,33 & 30,71 & 40,22 & 42,55 \\
\hline$A_{0} M_{3}: A_{2} M_{1}$ & 57,88 & 56,14 & 55,89 & 47,25 & 41,48 & 66,10 \\
\hline $\mathrm{A}_{0} \mathrm{M}_{3}: \mathrm{A}_{2} \mathrm{M}_{2}$ & 39,06 & 57,68 & 58,43 & 63,84 & 43,49 & 64,11 \\
\hline $\mathrm{A}_{0} \mathrm{M}_{3}: \mathrm{A}_{2} \mathrm{M}_{3}$ & 48,46 & 74,26 & 10,76 & 21,78 & 23,40 & 68,69 \\
\hline$A_{1} M_{0}: A_{1} M_{1}$ & 28,85 & 52,37 & 30,02 & 29,91 & 45,49 & 76,62 \\
\hline$A_{1} M_{0}: A_{1} M_{2}$ & 43,25 & 54,83 & 32,23 & 25,56 & 35,15 & 69,68 \\
\hline$A_{1} M_{0}: A_{1} M_{3}$ & 45,97 & 46,80 & 21,10 & 13,53 & 32,12 & 60,53 \\
\hline$A_{1} M_{0}: A_{2} M_{0}$ & 59,54 & 52,68 & 50,18 & 10,13 & 60,37 & 47,59 \\
\hline$A_{1} M_{0}: A_{2} M_{1}$ & 60,62 & 56,76 & 30,02 & 53,01 & 39,98 & 64,48 \\
\hline$A_{1} M_{0}: A_{2} M_{2}$ & 45,01 & 52,30 & 30,02 & 14,99 & 60,96 & 58,51 \\
\hline$A_{1} M_{0}: A_{2} M_{3}$ & 22,73 & 54,17 & 15,83 & 0,00 & 22,36 & 64,39 \\
\hline$A_{1} M_{1}: A_{1} M_{2}$ & 30,46 & 36,17 & 43,21 & 46,02 & 24,26 & 62,79 \\
\hline$A_{1} M_{1}: A_{1} M_{3}$ & 35,73 & 54,49 & 14,19 & 16,79 & 20,54 & 52,88 \\
\hline$A_{1} M_{1}: A_{2} M_{0}$ & 28,82 & 40,83 & 24,75 & 10,14 & 31,68 & 41,41 \\
\hline$A_{1} M_{1}: A_{2} M_{1}$ & 33,37 & 57,40 & 66,07 & 29,91 & 34,70 & 63,16 \\
\hline$A_{1} M_{1}: A_{2} M_{2}$ & 32,86 & 55,75 & 66,22 & 57,94 & 39,19 & 58,65 \\
\hline$A_{1} M_{1}: A_{2} M_{3}$ & 33,72 & 63,72 & 59,41 & 37,65 & 10,73 & 57,22 \\
\hline$A_{1} M_{2}: A_{1} M_{3}$ & 47,32 & 53,87 & 0,00 & 16,79 & 5,94 & 63,42 \\
\hline$A_{1} M_{2}: A_{2} M_{0}$ & 41,63 & 50,53 & 41,13 & 10,21 & 21,70 & 43,11 \\
\hline$A_{1} M_{2}: A_{2} M_{1}$ & 42,38 & 46,81 & 43,21 & 25,56 & 34,14 & 79,69 \\
\hline$A_{1} M_{2}: A_{2} M_{2}$ & 44,63 & 50,53 & 32,67 & 20,46 & 35,52 & 60,15 \\
\hline$A_{1} M_{2}: A_{2} M_{3}$ & 61,72 & 49,04 & 32,67 & 74,44 & 23,40 & 68,11 \\
\hline$A_{1} M_{3}: A_{2} M_{0}$ & 39,53 & 67,41 & 0,00 & 20,27 & 14,95 & 37,28 \\
\hline$A_{1} M_{3}: A_{2} M_{1}$ & 42,48 & 58,30 & 14,19 & 13,53 & 20,90 & 72,65 \\
\hline$A_{1} M_{3}: A_{2} M_{2}$ & 35,10 & 68,44 & 14,19 & 30,32 & 17,45 & 41,58 \\
\hline$A_{1} M_{3}: A_{2} M_{3}$ & 44,50 & 66,32 & 0,00 & 16,79 & 0,00 & 65,60 \\
\hline $\mathrm{A}_{2} \mathrm{M}_{0}: \mathrm{A}_{2} \mathrm{M}_{1}$ & 60,13 & 60,30 & 39,39 & 20,57 & 23,51 & 40,10 \\
\hline $\mathrm{A}_{2} \mathrm{M}_{0}: \mathrm{A}_{2} \mathrm{M}_{2}$ & 78,24 & 73,81 & 12,18 & 20,27 & 51,15 & 44,61 \\
\hline $\mathrm{A}_{2} \mathrm{M}_{0}: \mathrm{A}_{2} \mathrm{M}_{3}$ & 31,25 & 58,47 & 12,18 & 10,21 & 26,40 & 23,65 \\
\hline $\mathrm{A}_{2} \mathrm{M}_{1}: \mathrm{A}_{2} \mathrm{M}_{2}$ & 45,23 & 78,26 & 72,79 & 21,99 & 55,52 & 54,59 \\
\hline $\mathrm{A}_{2} \mathrm{M}_{1}: \mathrm{A}_{2} \mathrm{M}_{3}$ & 31,60 & 72,51 & 38,47 & 0,00 & 10,73 & 77,98 \\
\hline $\mathrm{A}_{2} \mathrm{M}_{2}: \mathrm{A}_{2} \mathrm{M}_{3}$ & 42,67 & 73,39 & 51,19 & 37,65 & 10,73 & 49,28 \\
\hline
\end{tabular}

Keterangan: $A_{0}=$ tanpa asam asetat, $A_{1}=$ asam asetat 22,5 I.ha ${ }^{-1}, A_{2}=$ asam asetat 31,5 I.ha ${ }^{-1}$ $\mathrm{M}_{0}=$ tanpa metil metsulfuron, $\mathrm{M}_{1}=$ metil metsulfuron $82,5 \mathrm{gr}^{-1} \mathrm{ha}^{-1}, \mathrm{M}_{2}=$ metil metsulfuron 112,5 gr.ha ${ }^{-1}, M_{3}=$ metil metsulfuron 157,5 gr.ha $^{-1}$

Nilai Koefisien Komunitas (C)

Nilai C digunakan untuk mengetahui pengaruh perlakuan terhadap pergeseran gulma pada suatu komunitas antara waktu 50 pengamatan, ulangan, dan perlakuan tidak berbeda atau seragam. Jika lebih kecil dari $75 \%$ maka berbeda atau tidak seragam. Nilai 
Jurnal Agroteknologi, Vol. 11 No. 2, Februari 2021: 45 - 52

koefisien komunitas total dapat dilihat pada Tabel 4.

Pergeseran komposisi gulma adalah perubahan spesies gulma pada tiap waktu pengamatan. Tindakan yang dilakukan terhadap gulma dapat mengakibatkan pergeseran gulma setelah aplikasi herbisida (Nurjannah, 2003).

\section{KESIMPULAN DAN SARAN}

\section{Kesimpulan}

Berdasarkan hasil pembahasan dari kegiatan penelitian yang dilakukan dapat disimpulkan bahwa herbisida metil metsulfuron dan asam asetat pada dosis yang diberikan belum mampu mengendalikan pertumbuhan gulma pada lahan tanaman tebu dan tidak ada interaksi pada herbisida metil metsulfuron dan asam asetat.

\section{Saran}

Perlu dilakukan penelitian lanjutan dengan menggunakan berbagai jenis herbisida sistemik dan herbisida kontak pada interval waktu yang berbeda untuk dapat mengendalikan gulma pada lahan tebu. Penggunaan dosis herbisida metil metsulfuron dan asam asetat sebaiknya menggunakan dosis terendah agar tidak merusak lingkungan dan efisiensi biaya.

\section{DAFTAR PUSTAKA}

Barus, E. 2003. Pengendalian Gulma di Perkebunan. Yogyakarta: Kansius.

Loganandhan. N, B. Gujja, V. Vinad Goud, dan U. S. Natarajan. 2012. Sustainable Sugarcane Initative (SSI): A Methodology of More Mith Less. Sugar Tech.

Nurjannah, U. 2003. Pengaruh dosis herbisida glifosat dan 2,4 - $d$ terhadap pergeseran gulma dan tanaman kedelai tanpa olah tanah. 5(1), 27-33.

Pramuhadi, G. 2012. Aplikasi Herbisida di Kebun Tebu Lahan Kering. Jurnal Pangan, 21(3): 221-231.

Prasetyo, T. 2016. Pergeseran Komposisi Jenis Gulma Akibat Pemberian Berbagai Tingkatan Dosis Herbisida Tunggal Diuron Pada Lahan Pertanaman Kakao (Theobroma cacao L.). Politeknik Negeri Lampung.

Pujisiswanto, H., Yudono, P., Sulistyaningsih, E., \& Bambang, $H$. 2014. Pengaruh Asam Asetat Sebagai Herbisida Pra Tumbuh Terhadap Pertumbuhan Gulma dan Perkecambahan Jagung. 131-138.
Puspitasari, K., Sebayang, H. T., \& Guritno, B. 2013. Pengaruh Aplikasi Herbisida Ametrin dan 2 , 4-D Dalam Mengendalikan Gulma Tanaman Tebu ( Saccharum Officinarum L .) The Effect Of Herbicide Ametrin And 2 , 4-D Application In Weed Control Of Sugar Cane ( Saccharum Officinarum L .). Jurnal Produksi Tanaman, 1(2), 72-80.

Sastroutomo, S. S. 1990. Ekologi Gulma. Jakarta: PT. Gramedia Pustaka Utama.

Sembodo, D. R. . 2010. Gulma dan Pengendaliannya. Yogyakarta: Graha IImu.

Sukman, Y., \& Yakub. 2002. Gulma dan Teknik Pengendaliannya. Jakarta: PT. Raja Grafindo Persada.

Wijaya, E., \& Nursyirwan. 2007. Pengendalian Gulma Dengan Herbisida Glifosat dan Metil Metsufuron Pada Tanaman Kelapa Sawit Menghasilkan Di Perkebunan P.T. Melania Indonesia Di Kecamatan Banyuasin Sumatra Selatan. Fakultas Pertanian. Universitas Sriwijaya. 
Pengaruh Herbisida Metil Metsulfuron Terhadap Gulma Tanaman Tebu (Setiawan, et al.) 